\title{
Socio-Cultural Factors as Determinant of Women's Attitude Towards Participation in Trade Unionism in Ondo State
}

\author{
Osalusi, F. M., Ph.D. \\ Department of Social Science Education, Faculty of Education, \\ Ekiti State University, Ado-Ekiti \\ Ajibefun, M. B. \\ School of Management Technology, \\ Federal University of Technology, Akure, Ondo State
}

\section{Doi:10.5901/mjss.2017.v8n3p335}

\section{Abstract}

\begin{abstract}
This study examined the issues of socio-cultural factors as determinants of women's attitude towards participation in trade unionism in Ondo State. The study adopted a descriptive research design of the survey type and a multi-stage sampling procedures. At stage one, purposive sampling technique was used to select five institutions out of the six government owned institutions in Ondo State. The one that was not selected was considered very young with no active labour union. Stage two involved the categorisation of staff in each institution into academic and non- academic using stratified sampling technique. Stage three involved the selection of fifty (50) respondents each from the institutions selected through random sampling technique making a total of five hundred (500) respondents as sample for the study. An instrument titled: 'Women Participation in Trade Unionism Questionnaire (WPTUQ)' designed by the researcher was used to collect data. The research questions were answered using descriptive statistics such as, frequency count, mean scores, percentages and standard deviations while hypotheses were tested using t-test and regression statistics as well as Pearson Product Moment Correlation analysis at 0.05 level of significance. Findings of the study revealed significant relationship between socio-cultural variables such as marital factors, age related factors, economic factors and women's participation in trade union activities. It was therefore recommended that women need to be encouraged to participate more actively in trade unionism. Also, religious institutions were advised to preach sermons in churches and mosques that would discourage gender bias. Also, women's education should be taken as priority to enhance their active participation in trade unionism.
\end{abstract}

Keywords: socio-cultural factors, determinant, attitude, religious affiliation, economic factors, trade unionism

\section{INTRODUCTION}

The definition of trade union varied according to the legal framework established in different countries of the world. For instance, Johnson (2003) opined that trade union laws in the UK described the term as the regulation of the relation between workmen and their masters; the imposing of restrictive conditions on the conduct of any trade or business; and the provision of benefits to members. The inception of modern trade union in Nigeria could be said to coincide with colonialism. Therefore, unlike the situation in most developed countries, Fajana, (2000) noted that trade union preceded industrialisation in Nigeria and it was a creation of the then British colonial government which was also influenced by events in other areas. Yusuf, (2013) reported that Nigerians under this situation were discouraged from belonging to unions as union membership was regarded as anti-colonial attitude. There were also limited wage employment while the few wage earners are colonial employers who are restricted to the colonial officers. Abdu (2003) reported that the experience in Sierra Leone greatly influenced the development of trade unionism in Nigeria. Omotola, (2007) noted that the first union was not formed by a group of dissatisfied workers who wanted a platform from which to fight for amelioration of grievances or for the improvement of specific conditions of employment but rather it was formed just to conform to what workers in Sierra Leone had done.

Promoting women active participation in all national activities have been globally adjudged as a developmental strategy that could reduce poverty level of women and also serve as a means of eradicating harmful practices against their interest. The 1999 Nigerian constitution provided for all citizens the right to participate in trade union or other associations of their choice for the protection of their interests. However, several factors such as traditions, values, 
customs, sexual stereotyping of social roles have always militated against the full participation of women in trade union movements. It is observed that participation of women, especially in terms of vying for leadership positions have been minimal since the inception of trade union movement in Nigeria. Yusuf (2013) observed that one of the reasons for this development is the patriarchal culture which significantly aids gender discrimination against women at work. He identified socio-cultural prejudices, inadequate laws and gender inequalities as part of the key factors militating against the promotion of women active participation in trade union activities.

The issue of women active participation in trade union activities in Nigeria gained significant attention after the transfer of power from the military regime to a civilian democratic administration in 1999. One would have thought that women would be involved equally in union activities based on the Beijing declaration that sees all unions as a democratic institution. However, there is ironically lack of awareness of gender issues amongst them. Women showed low level of interest and when they to feature, it is into women assumed social welfare role rather than key positions. It is therefore sad to note that the assertion which says democracy should boost women participation in trade unionism is yet to be a reality after eighteen years of civil rule. For example, Nigeria is yet to elect a female national leaders of these unionsNigeria Labour Congress (NLC), Teachers Union Congress (TUC), Academic Staff Union of Universities (ASUU), Nigerian Union of Local Government Employee (NULGE) and Nigeria Union of Teachers (NUT) since 1999.

Women in some parts of the world are regarded as weaker sex hence certain jobs and duties are considered not fit. Odi (2010) asserted that during the colonial period, education curricula even emphasised clerical skills for boys while domestic science is considered for girls. Besides, there was also a perception that women needed to be educated only to be good housewives. For instance, in Nigeria, women duties are believed to take care of their homes and husbands, give birth to children and bring them up in acceptable ways to the society. In the present days, there are indications that women are no longer perceived as weak but their conducts and beliefs are still controlled by socio-cultural factors of the society.

Considering the socio-cultural factors that could limit women active participation in trade union activities, age, level, education, economic, marital factors and religion affiliation seem to be likely correlation of various aspects of women's attitude on the issue. What is not clear however is the degree to which these factors are likely to uniquely influence women participation in trade union activities? This study therefore examined the extent to which these socio-cultural factors have determined women's attitude towards participation in trade unionism in Ondo State, Nigeria.

These questions were raised and answered:

1. Which socio-cultural variable influence women active participation in trade unionism?

2. What type of attitudes do women put up towards participation in trade unionism?

Based on the above, six hypotheses were tested. They are:

i. Marital factors will have no significant relationship with women attitude towards participation in trade unionism.

ii. Age factors will have no significant relationship with women attitude towards participation in trade unionism;

iii. Level of education factors will have no significant relationship with women attitude towards participation in trade unionism;

iv. Economic factors will have no significant relationship with women attitude towards participation in trade unionism;

v. Religious factors will have no significant relationship with women attitude towards participation in trade unionism.

vi. Socio-cultural variables will not significantly predict women participation in trade unionism.

\section{Research Method}

A descriptive research design of the survey type was adopted for the study. The population is made up of all female workers in government owned tertiary institutions in Ondo State, Nigeria. Five hundred (500) respondents were selected from five (5) tertiary institutions through multistage sampling procedures. In stage one, a purposive sampling technique was used to select five (5) out of six (6) government owned institutions in Ondo State, Nigeria. The sixth institution has no active labour unions due to its young age. Each institution was stratified into two,(academic and non academic) based on the existing administrative classification in each of the institutions. Fifty (50) respondents were randomly selected from each institution.

The instrument was a questionnaire designed by the researcher and it is tagged: "Women Participation in Trade Union Questionnaire (WPTUQ)". It contains socio-cultural variable information on economic, religious, marital and age related factors as well as qualification and occupation of women in relation to trade unionism. Validity of the instrument was determined by experts from the field of Social Studies, Tests, Measurements and Evaluation. The instrument was 
administered twice on twenty respondents in two tertiary institutions in Ekiti State within an interval of two weeks. The two institutions shared similar characteristics with the actual sample used and a co-efficient 0.84 was obtained which is a proof that the instrument is reliable. However, four hundred and sixty six (466) questionnaires were correctly filled and retrieved from the respondents. Descriptive statistics such as frequency counts, mean scores, percentages, standard deviation, were used in answering questions raised while t-test, regression and Pearson Product Moment Correlation analysis were employed in testing the hypotheses at 0.05 level of significance.

\section{Results}

\subsection{Question 1: Which socio-cultural variable influence women participation in trade unionism.}

The average mean of scores of each socio- cultural variable were computed as presented in table 1, bearing in mind that the mean cut off is 3.00 .

Table 1: Descriptive analysis showing Socio-cultural variables that determine women participation in trade unionism

\begin{tabular}{|l|c|c|c|c|}
\hline Socio-cultural variable & N (F) & Mean & Std. Dev & Remark \\
\hline Marital factors & 466 & 3.58 & 1.28 & $3.58>3.00^{\star}$ \\
\hline Age related factors & 466 & 3.37 & 1.30 & $3.37>3.00^{*}$ \\
\hline Level of Education & 466 & 2.73 & 1.39 & $2.73<3.00$ \\
\hline Economic Factors & 466 & 3.79 & 1.24 & $3.79>3.00^{\star}$ \\
\hline Religious factors & 466 & 2.86 & 1.40 & $2.86<3.00$ \\
\hline
\end{tabular}

Mean cut-off: $3.00 \quad$ Determinant*

This table shows that marital factors have mean score of 3.58, age related factors have mean score of 3.37 , level of education has a mean score of 2.73, economic factors have mean score of 3.79; and religious factors have mean score of 2.86. With the mean cut-off of 3.00 , it is concluded that marital factors, age related factors and economic factors have relationship with women's participation in trade unionism. Level of education has the least relationship with a mean score of 2.73. Religious factors also recorded a no significant relationship with a mean score of 2.86 .

\subsection{Question 2: What type of attitudes do women put up towards participation in trade unionism?}

The frequency counts, percentages, mean and standard deviation on items relating to attitude of women towards participation in trade unionism were computed as presented in table 2.

Table 2: Descriptive analysis showing attitudes of women towards participation in trade unionism

\begin{tabular}{|l|l|c|c|c|c|c|c|}
\hline \multirow{2}{*}{$S / N$} & Items & $\begin{array}{c}\boldsymbol{N} \\
\mathbf{F}\end{array}$ & $\begin{array}{c}\text { Agreed \% of } \\
\text { respondents }\end{array}$ & $\begin{array}{c}\text { Undecided \% of } \\
\text { Respondents }\end{array}$ & $\begin{array}{c}\text { Disagreed \% of } \\
\text { Respondents }\end{array}$ & Mean & SD \\
\hline & Attitude & & & & & & \\
\hline 1. & $\begin{array}{l}\text { Women show interest in participating in trade } \\
\text { unionism. }\end{array}$ & 466 & $343(73.61 \%)$ & $36(7.73 \%)$ & $87(18.67 \%)$ & 3.78 & 0.98 \\
\hline 2. & $\begin{array}{l}\text { Women are motivated when they come together to } \\
\text { fight a common goal. }\end{array}$ & 466 & $397(85.19 \%)$ & $23(4.94 \%)$ & $46(9.87 \%)$ & 4.10 & 1.06 \\
\hline 3. & $\begin{array}{l}\text { Women participate actively in any act to fight for } \\
\text { their rights. }\end{array}$ & 466 & $356(76.39 \%)$ & $45(9.66 \%)$ & $65(13.95 \%)$ & 3.92 & 1.02 \\
\hline 4. & $\begin{array}{l}\text { Women see trade unionism as a fruitless effort to } \\
\text { agitate for members' right and privileges. }\end{array}$ & 466 & $139(29.82 \%)$ & $62(13.30 \%)$ & $265(56.87 \%)$ & 2.65 & 0.88 \\
\hline 5. & $\begin{array}{l}\text { Women see decision making concerning public } \\
\text { affairs as the duty of men. }\end{array}$ & 466 & $155(33.26 \%)$ & $54(11.59 \%)$ & $257(55.15 \%)$ & 2.68 & 0.86 \\
\hline
\end{tabular}

In table 2, 73.61\% women have interest in participating in trade unionism, $7.73 \%$ were undecided while $18.6 \%$ disagreed. Also $85.19 \%$ agreed that women are motivated when they come together to fight a common goal, $4.94 \%$ were undecided while $9.87 \%$ disagreed. 76 . 39\% agreed that women participate actively in any act to fight for their rights, $9.66 \%$ were undecided while $13.95 \%$ disagreed. Only $29.82 \%$ agreed that women see trade unionism as a fruitless efforts to agitate 
for member's right and privileges, $13.30 \%$ were undecided while $56.87 \%$ disagreed. $33.26 \%$ agreed that women see decision-making concerning public affairs as the duty of men, $11.59 \%$ were un decided while $55.15 \%$ disagreed. It can therefore be concluded that the attitudes of women in the study is an indication that they have interest in participation in trade unionism and that they are motivated when they come together to fight a common goal as they participate actively in any act to fight for their rights. They also see trade unionism as a fruitful effort to agitate for members' right and privileges. However, they don't see decision-making concerning public affairs as the duty of only men but as the duty of men and women.

\subsection{Testing of Hypothesis:}

i. Marital factors will have no significant relationship with women attitude towards participation in trade unionism. Mean scores of marital factors were correlated for significance with women attitude towards participation in trade unionism as presented.

Table 3: t-test analysis on marital factors and women participation in trade unionism

\begin{tabular}{|c|c|c|c|c|c|c|}
\hline Variables & $N$ & Mean & Std. dev. & $r$-cal & $r$-tab & Remark \\
\hline Marital factors & 466 & 3.58 & 1.28 & & & \\
\hline Women participation in trade unionism. & 466 & 3.43 & 1.03 & $0.318^{*}$ & 0.087 & Significant \\
\hline
\end{tabular}

In table $3, \mathrm{r}$-cal $(0.318)$ is greater than $\mathrm{r}$ - table $(0.87)$ indicating a relationship of marital factors with women participation in trade unionism.

ii. Age factors will have no relationship with women attitude towards participation in trade unionism.

Mean scores of items on age factor with women participation in trade unionism were correlated for statistical significance as presented.

Table 4: t-test analysis of age factors with women participation in trade unionism

\begin{tabular}{|l|c|c|c|c|c|c|}
\hline Variables & $\boldsymbol{N}$ & Mean & Std. dev. & $\boldsymbol{r}$-cal & $\boldsymbol{r}$-tab & Remark \\
\cline { 1 - 5 } Age related factors & 466 & 3.37 & 1.30 & & & \\
\cline { 1 - 5 } Women participation in trade unionism & 466 & 3.43 & 1.03 & $0.502^{*}$ & 0.087 & Significant \\
\hline
\end{tabular}

In table $4, r$-cal $(0.502)$ is greater than r-table $(0.087)$ indicating a relationship of age factors with women participation in trade unionism.

iii. Level of education will not have significant relationship with women attitude towards participation in trade unionism.

Mean scores of items on level of education and women participation in trade unionism were correlated for statistical significance as presented.

Table 5: t-test statistics on level of education factors and women participation in trade unionism

\begin{tabular}{|l|c|c|c|c|c|c|}
\hline Variables & $\boldsymbol{N}$ & Mean & Std. dev. & $\boldsymbol{r}$-cal & $\boldsymbol{r}$-tab & Remark \\
\hline Level of education factors & 466 & 2.73 & 1.39 & & & \\
\cline { 1 - 5 } Women participation in trade unionism & 466 & 3.43 & 1.03 & $0.346^{*}$ & 0.087 & Significant \\
\hline
\end{tabular}

Table 5 indicate $r$ - cal $(0.346)$ greater than $r$ - table $(0.087)$ which means that level of education has relationship with women participation in trade unionism.

iv. Economic factors will have no significant relationship with women attitude towards participation in trade unionism.

Mean scores of items on economic factors and women participation in trade unionism were correlated for statistical significance as presented. 
Table 6: t-test statistics on Economic factors of women participation in trade unionism

\begin{tabular}{|l|c|c|c|c|c|c|}
\hline Variables & $\boldsymbol{N}$ & Mean & Std. dev. & $\boldsymbol{r}$-cal & $\boldsymbol{r}$-tab & Remark \\
\hline Economic factors & 466 & 3.79 & 1.24 & & & \\
\cline { 1 - 5 } Women participation in trade unionism & 466 & 3.43 & 1.03 & $0.313^{*}$ & \multirow{2}{*}{0.087} & Significant \\
\hline
\end{tabular}

In the above results, $r$-cal $(0.313)$ is greater than $r$ - table $(0.087)$. This implies that economic factors have relationship with women participation in trade unionism.

v. Religious factors will have no significant relationship with women attitude towards participation in trade unionism.

Mean scores on religious factors and women participation in trade unionism were correlated for statistical significance as presented.

Table 7: t-test statistics of Religious factors and women participation in trade unionism

\begin{tabular}{|l|c|c|c|c|c|c|}
\hline Variables & $\boldsymbol{N}$ & Mean & Std. dev. & $\boldsymbol{r}$-cal & $\boldsymbol{r}$-tab & Remark \\
\hline Religious Factors & 466 & 2.86 & 1.40 & & & \\
\cline { 1 - 5 } Women participation in trade unionism & 466 & 3.43 & 1.03 & $0.401^{*}$ & 0.087 & Significant \\
\hline
\end{tabular}

The $r$-cal $(0.401)$ is greater than $r$ - table $(0.087)$ which means that religious factors have relationship with women participation in trade unionism.

vi. Socio-cultural variables will not significantly predict women participation in trade unionism.

Regression analysis was used to examine the contributions of each of the independent variables to the dependent variable as presented.

Table 8: Regression analysis relationship between the criterion variable and the five independent variables.

\begin{tabular}{|c|c|c|c|c|c|c|c|}
\hline Variables & $\begin{array}{c}\text { Un-standardised coefficients } \\
\text { (Beta) }\end{array}$ & $\begin{array}{l}\text { Std } \\
\text { error }\end{array}$ & $\begin{array}{c}\text { Standardized coefficients } \\
\text { (Beta) }\end{array}$ & t-stat. & $R$ & $R^{2}$ & $F$ \\
\hline Marital factors & -.174 & .053 & -.177 & -3.305 & \multirow{5}{*}{0.967} & \multirow{5}{*}{0.936} & \multirow{5}{*}{1336.38} \\
\hline Age related factors & .371 & .044 & .384 & 8.345 & & & \\
\hline Level of education & .292 & .045 & .322 & 6.478 & & & \\
\hline Economic factors & .083 & .041 & .082 & 2.016 & & & \\
\hline Religious factors & .342 & .052 & .381 & 6.623 & & & \\
\hline Constant & .159 & .052 & & 3.082 & & & \\
\hline
\end{tabular}

The result indicate that the five predictors accounted for $94 \%$ towards women participation in trade unionism, $\left(\mathrm{R}^{2}=\right.$ 0.936), $F(5,466) m=1336.38$. Marital Status .177, age of women .384, level of education .322, Economic factors .082, and Religion . 381, demonstrated effects of the variables on women participation in trade unionism.

The coefficient of the model indicate that the five variables can be ranked from best to least in order to quantify their influence on the dependent variable starting with Age of women (.384), Religion (.381), Level of Education (.322), Marital status (.177) and Economic Factors (.082).

\section{Discussion}

The study revealed that women show interest in participating in trade unionism, motivated when they come together to fight for a common goal, participate actively in any act to fight for their rights, see trade unionism as a fruitful effort to agitate for member's rights and privileges and do not see decision making concerning public affairs as the duty of men alone but equal representation of both men and women. However, the report of International Labour Organisation (ILO) as highlighted by Folorunsho (2011) observed that women held less than a third of senior decision-making posts in over $60 \%$ of trade unions studied. The report further submitted that women account for an increasing proportion of the workforce, appear to have more concern for the welfare of others psychologically and that gender equality will help unions to strengthen and reaffirm their key roles as agents of social change and also provide common grounds to forge alliances with other social actors hence, women should be encouraged to actively participate in trade union activities. 
There is also a significant relationship of marital factors with women attitude towards participation in trade union activities in this study in line with the findings of Magidu (2010). He found out that married males have the highest rate of participation in trade unionism while the separated/divorced has the highest participation rate among the female and married women recorded the lowest rate of participation. The result might not be unconnected with the pressure of responsibilities in the households on married women. For instance, Sackey (2005) observed that women tend to be more preoccupied with household activities and as the size of family members increases, the responsibilities becomes more intensive. Also, level of education of women was seen as a factor. Anugwom (2009) reported that women with no formal education and those with primary education have the lowest level of participation in trade unionism, secondary school graduates exhibits a moderate level of participation while the tertiary education graduates exhibit the highest level of participation in trade unionism.

The result of this study indicated that economic factors equally have relationship with women attitude towards participation in trade unionism. This finding buttresses the position of Ahmed (2007) on trade unionism and trade union movements. He reported that economic empowerment is essential for realising women's full potentials in making appreciable contributions through active participation in trade union activities. Bill and Melinda Gates Foundation (2010) reported that some societal values assumed that union activities are masculine hence, women most of the time depend on their husbands for active participation, this reveals the extent of financial incapacitation of women in trade union movements. Also, women generally may be unwilling to commit their financial resources to political activities but would rather prefer to invest on their children and other family responsibilities as well as on some economic activities where they could have positive returns.

Religious factors also revealed a relationship with women participation in trade unionism. For example, Anifowose, (2004) and Bari, (2005) reported a strong religious affiliation and institutional arrangements that restricted women to family responsibilities as well as partial exclusion of women from political activities in the society. In Nigeria, Nmadu (2000) observed that the society is significantly dotted with peculiar religious/cultural practices that are inimical to women's emancipation. Example could be drawn from early/forced marriage, wife-inheritance, widowhood practices and patriarchy system. Bari (2005) noted that patriarchy system is characterized by male kinship, permanent marriage and paternal authority and that the mechanism of gender segregation restricts women empowerment by limiting their exposure to interact with male and female constituents and address public meetings. This to Oyekanmi (2004) enables men to dominate women and hence, made women powerless and dependent on men. Adeniran (2006) advised that such unequal social and gender relations need to be transformed in order to take women out of want and poverty. Anifowose (2004) went further to say that this beliefs are observed to be dying gradually in the society now. Among the five variables, age of women has the highest significant relationship while level of education constitutes the least predictor in this study.

\section{Conclusion}

From the study, age related factors, marital factors, and economic factors determine women attitude towards participation in trade unionism. Age is the best predictor while level of education is the least predictor of women participation in trade unionism.

\section{Recommendations}

1. There is need for the reformation of religious institutions to avoid discrimination against women involvement in public life. The patriarchal structures that reinforce power imbalance between women and men need to be dismantled.

2. Women of all age groups should be encouraged and motivated to participate in trade union activities. Discrimination among age groups should be totally avoided and older women need not leave the struggle to the young ones.

3. Great importance need to be placed on the education of women to give them courage and confidence in participating in union activities.

4. Economic empowerment strategies at the level of policy-decisions and policy-framework should be adopted to improve lives of women and men in equal measure. 


\section{References}

Abdu, H. (2003). Power in the name of Allah: Muslim women in contemporary nigerian politics'. Lagos: Centre for Social Science Research and Development.

Adeniran, A. (2006). A non-dependent framework for development. Thisday, Wednesday, August 23, p. 45.

Ahmed, S. (2007). Poverty alleviation and empowerment of women: The BRAC experience in putting gender mainstreaming into practice. Economic and Social Commission, Asia and the Pacific.

Anifowose, R. (2004). Women political participation in Nigeria: Problems and prospects. In C. Akinboye (ed), Paradox of gender equality in Nigerian politics. Lagos: Concept Publications.

Anugwom, E. E. (2009). Women, education and work in Nigeria. Educational Research and Review, 4(4): 127-134.

Bari, F. (2005). Women's trade unionism and political participation: Issues and challenges. United Nations Division for the Advancement of Women (DAW) EGM/WPD-EE/ 2005/EP.12.

Bill \& Melinda Gates Foundation (2010). Improving opportunities for women in smallholder-based supply chains: Business case and practical guidance for international food companies. Gates Foundation, Seattle.

Fajana, S. (2000). Functioning of the Nigerian labour movement. Lagos: Lobofin \& Co.

Folorunsho, O. (2011). The role of women in trade unions and nation building. www.pengassan. Accessed in August.

Johnson, C. (2003). 'Why Nigerian women fail in elections'. Lagos: ThisDay, September 30. Retrieved on April 18, 2008 from the website.

Magidu, N. (2010). Socio-economic investigation into determinants of labour force participation in labour markets: Evidence from Uganda. Mimeo. Economic Policy Research Centre, http://www.iza.org/conference_files/worldb2010/nyede_m6067.pdf. Accessed on December 27, 2015.

Nmadu, B. (2000). On our feet. Women in grassroot development. Journal of Women in Academics, 1(1): 165-171.

Odi, M. (2010). The power of women's collective action. Lagos: Muhamsaid Press.

Omotola, S. J. (2007). What is the gender talk all about after all? Gender, power and politics in contemporary Nigeria. African Study Monographs, 28(1): 56-71.

Oyekanmi, F. D. (2004). Socio-economic dimension of gender equality. In C. Akinboye (ed) Paradox of gender equality in Nigerian politics. Lagos: Concept Publications.

Sackey, H. A. (2005). Female labour force participation in Ghana: The effects of education. AERC Research Paper 150, Nairobi.

Yusuf, N. (2013). Trade union movement and workers emancipation within the context of contrasting political climate in Nigeria. Retrieved from https://unilorin.edu.ng/ publications/union.html. 
ISSN 2039-2117 (online)

ISSN 2039-9340 (print)
Mediterranean Journal of Social Sciences MCSER Publishing, Rome-Italy
Vol 8 No 3

May 2017 